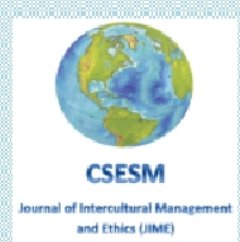

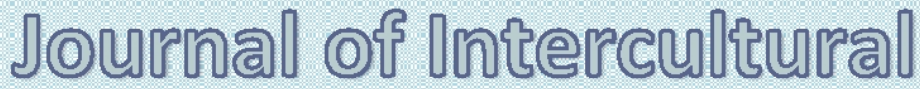

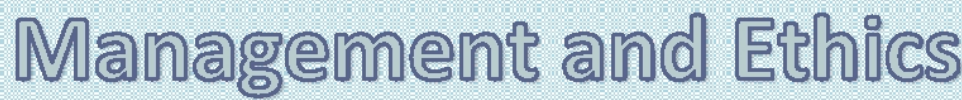

\author{
IOME
}

ISSN 2601 - 5749, ISSN-L 2601 - 5749

\section{published by zy \\ Center for Socio-Economic Studies and Multiculturalism \\ lasi, Romania \\ Waw csesmorg}




\section{Special Editor}

\section{Professor Beatrice Gabriela Ioan, PhD, MD}

Grigore T.Popa University of Medicine and Pharmacy of Iasi, Romania

E-mail: ioanbml@yahoo.com

\section{TABLE OF CONTENT}

Editorial ....

Beatrice Gabriela Ioan

Ethical Approaches on the Mandatory Vaccination in the Pandemic Context (Romania Case)

Andreea-Iulia Someșan, Ion Copoeru

Early Approaches in Management of Sars-Cov-2 Infection 19

Isabela-Ioana Loghin, Adriana-Florina Bahnă, Oana-Manuela Secrieru, Irina-Margareta

Nistor, Irina-Cristina Nicolau, Liviu Jany Prisăcariu, Florin Roșu, Victor Daniel Dorobăţ,

Cristin-Ioan Loghin, Carmen-Mihaela Dorobăț

Giving Birth during the Pandemic. How The Decision to Transform Certain Hospitals In Dedicated Covid-19 Medical Units Impacted Women on Psychological Level

Alexandra Ștefania Nadane

Evangelicalism in Uganda: Implications for Public Health and Bioethics

Sana Loue, Francis Bajunirwe

The Contribution of Ethics to the Development of the Healthcare System

Cornelia Margareta Găşpărel

Iatrogenesis Induced by Risk Reduction in Health Care

Mircea Gelu Buta

Ethical Contributions in Preserving the Dignity of the Terminal Patient

Elena Toader, Andreea Decusara, Mirela Piscuc, Tudor Winsinger

Ethical Aspects of the Institutionalization Process of Children from Outbreaks of

Tuberculosis

Rodica Gramma, Elena Cernăuțeanu, Adriana Paladi

Profession, Vocation, Mission or Work. The Ancient Physician and the Contemporary

Physician-Parallel Lives

Orsolya Horber, K.Zilahi 


\title{
ETHICAL APPROACHES ON THE MANDATORY VACCINATION IN THE PANDEMIC CONTEXT (ROMANIA CASE)
}

\author{
Andreea-Iulia Someşan ${ }^{1, *}$, Ion Copoeru ${ }^{1}$ \\ ${ }^{1}$ Doctoral School of Philosophy, "Babes-Bolyai" University, Cluj-Napoca, Romania \\ * corresponding author, E-mail: somesan.andreea.iulia@gmail.com)
}

\begin{abstract}
The present pandemic situation created the context for the promulgation of a new legislation for certain public health issues with the intrusion into the citizens' private life. In addition, the medical professionals consider that returning to a normal life would be possible only after the majority of the population will be vaccinated. Although the Oviedo Convention promotes, without exception, informed consent to any medical intervention, by enacting specific legislation for mandatory vaccination, it will no longer be necessary to obtain the patient's consent. How will vaccination campaigns be implemented and carried out in that context? Can this approach regarding the exercise of external decision-making authority in the field of individual actions find other patterns of justification? What would be the impact of the mass vaccinations by compulsion on the individual? The purpose of this paper is to discuss the ethico-philosophical aspects of mandatory vaccination in a pandemic context and to analyze the possible objections to it by referring to the history of the movement against vaccination.
\end{abstract}

Keywords: autonomy, consent, opposition, mandatory vaccination, pandemic

\section{Introduction}

The spreading of the Covid-19 pandemic around the world created the urgency of taking important medical decisions in a short term. Consequently, the process of developing a vaccine was speed-up: the vaccine against Covid-19 was released on the marketing in about 6-8 months (Katznelson, 2020). Because of the shortness of the Covid-19 vaccines testing, there were raised rumors about the medium and long term side effects of vaccination. Based on this view, the time was too short to observe how the body and the immunity react to the vaccine. A few studies on the Covid-19 vaccine hesitancy were conducted in the last months to have a better understanding on finding the right manner to lead successfully the vaccination campaign (UPMC, 2020).

To understand the hesitance of a certain part of the population toward the vaccination campaign against Covid-19, we should consider that here it is about a believe system built by convergence of at least three factors: the attitude toward the medical system in general, the views on the vaccination as prevention method and the information acquired on the development of the Covid-19 vaccines.

Firstly, we should consider the fact that a certain part of the population will have the suspicion tendency about any medical recommendation. It can be here an issue about the discrepancy (Hirsch, 2007, p. 512) between the subjective perceptions of the illness by the patient and the objective view of the healthcare professional on the same medical condition (Foucault, 2003). The main reason of the patient to refuse a certain recommendation could be based on his impression of not being understood by his medical doctor. This person may consider that the personal embodied perceptions of the disease are misinterpreted. The patient may have this impression concerning his physician because of his the willingness of to know more about his medical condition and the tendency of self-diagnose. Therefore, by his 
independent research the patient will obtain information from multiple sources. A healthcare professional could find even some contradictions in that amount of information because some of the sources are, usually, without any medical accreditation and based on some unreplicable cases. Moreover, some online resources even talk about the reasons why to keep prudence in considering the health professionals' recommendations. Even if there may be justified reasons for preferring a different treatment, the patient may develop doubts based on unsupported arguments (Danzon, 2010).

After the doubting attitude concerning the accredited medical knowledge, the patient may also have concerns about the vaccination itself. Therefore, the following section highlights some legal texts that may give support to the vaccination refusal. We will also consider the clinical approach on different cases, some of them not reacquiring the written expression of the patient's consent.

But concerning the common vaccination practice, the adult population is usually vaccinated with the verbal consent. They can also decide for not getting a vaccine, situation that may involve some consequences for them as citizens.

In the case of vaccination campaigns against Covid-19, the patient will offer his written consent (Parliamentary Assembly, 2021). Those who hesitate on the idea of getting vaccinated against Covid-19 spread rumors about a future context when the authorities will not take into account their refusal or a future probability of conditioning other rights guaranteed in the present by the Constitution and international laws - by a kind of proof of their vaccination. The aim of this paper is to analyze and to build an ethico-philosophical approach which could be useful for the government and medical institutions in dealing with some groups' hesitancy on Covid-19 vaccines (Pepplinkhuizen, 2020).

\section{Legal and clinical practice aspects concerning the vaccination refusal (in Europe and Romania)}

From the Nuremberg Code (Hirsch, 2007 p. 159-167), the respect of the fundamental human rights in medical field was a concern at international level from different approaches. As a consequence, many other legislative texts were enacted later to establish the necessity of obtaining the patient's consent - free and well informed - for any medical intervention.

One of the most important international documents on this topic is the Oviedo Convention (Council of Europe, 1997), enacted in 1997 by the member states of the Council of Europe. The goal was the establishment, at the international level, standards concerning the respect of the rights and the human dignity in the context of life sciences. The second chapter of the Convention mentions the obligation to respect the consent of the patient as one of the most important pillars in preserving his freedom and the dignity in the medical context. Thus, the fifth article of the Convention presents the general rule of applying the informed consent rule:

„An intervention in the health field may only be carried out after the person concerned has given free and informed consent to it.

This person shall beforehand be given appropriate information as to the purpose and nature of the intervention as well as on its consequences and risks.

The person concerned may freely withdraw consent at any time." (Council of Europe, 1997)

In the case of a competent person, without exceptions, the consent should be obtained for any medical intervention which is not in an emergency: like in the case of outpatient appointments, hospitalizations. This person also has the right to "withdraw [his] consent at any time". The procedure to be applied in the case of a person who is not able to offer his consent is mentioned in Chapter II, Article 6 (Council of Europe, 1997) and the Article 8 of the sames chapter writtes about the emergency context. 
At the international level, the written consent is due in some cases (like in the case of an experimental protocol, surgical interventions, hospitalizations), but, most of the time, the patient will offer his consent by speech to the health professionals. (Aluaş, 2016, p. 50) This is an act of trust on the physician to follow the proposed treatment. In the case of surgical intervention or experimental treatments and procedures, even the Romanian legislation mention about the mandatory written consent. However, the medical staff has to provide enough information about benefits, risks and alternatives. Therefore, the patient himself must take the decision, free from any constraint or manipulation.

The Code of Medical Deontology elaborated by Romanian Medical College follow the European recommendation concerning the good practice in obtaining the consent:

"Chapter. II - Consent ART. 11 Granting and withdrawal of consent (1) No intervention in the field of health may be carried out only after the data subject has given his or her free and informed consent. 2. Under the same conditions, consent may be withdrawn at any time by the data subject. (3) The provisions regarding the withdrawal of consent are also valid with regard to the consent expressed, in accordance with the law, by a person or institution other than that person." (Colegiul Medicilor din România, 2016)

In addition, the Law no. 46/2003 mentions, in Chapter III, Article 13, about the written refusal of a required medical intervention with a large impact on the individual's health: "The patient has the right to refuse or to stop a medical intervention assuming, in writing, the responsibility for his decision" (Parlamentul României, Legea nr. 46/ 2003) The same article mentions the obligation of the medical doctor to explain the consequences of his decision. By a literal reading of this article, the healthcare professional is not allowed to say anything that will constrain or manipulate the patient to take a certain decision. And, because of the context, the consequences presented to the patient should refer just to the medical aspects on the topic at that moment. The law does not mention explicitly about the social implications of the medical decisions; therefore, these are not to be taken as arguments for supporting a certain decision. Thus, the following phrase - despite of its truths - in said by a physician "If you will not get vaccinated, you may not be able to work in a social environment." could be interpreted as a transgression of the ethical and deontological principles of the medical profession. The Article 16 of the Chapter III from the same law mentioned above wrtites about the cases when the patient doesn't have the legal right to make the decision, this person still should be involved in "the decision-making process as far as his capacity for understanding allows it." (Parlamentul României, Legea nr. 46/ 2003) Here we can mention the minors or the mental alienated people who have to undergo to certain medical interventions.

In the emergency case, when the life of the patient is in an imminent danger, the medical staff will be in charge with the decision about the medical treatment chosen or the procedure applied. The second situation mentioned by the Law no. 46/2003, article 17, of the health professionals to be in charge with the medical decision is when the legal representative of the patient refuses to give his consent for a necessary medical intervention.

The mentioned legislative texts don't make any difference between the therapeutic medical interventions and the preventive ones. A lot of debates in the humanities go around the status of the individual in the medical context. The debates are also focused on the concepts more likely to be used, despite of their roots' meaning, with the interpretation assigned by the relationship of the individual with the medical staff. Therefore, the idea of being the sick person became a conceptual construct used in the clinical context to label, in relation with his medical condition, the receiver of the medical support: this person is seen as suffering from an illness - his disease being more important than himself as a person. (Chamayou, 2014) The patient, as a conceptual construct, gives the name to the relationship 
built between the individual and his physician, even if nowadays the focus is not anymore on the illness, but on status of the person as the client of the healthcare system. Moreover, the consumerist approach of the medical care I focused to replace the binomial of health / illness with the quality of life concept. (Aluaş, 2016, p. 31) WHO contributed to the establishment of some objectives criteria, by the quality of life construct, to consider a medical condition as worth living (Aluaş, 2016, p. 36). The medical intervention is not anymore performed just because of the patient's demand, but it is instituted as an act of authority, many areas of the life being medicalized (Iacob, 2013, p. 59). Therefore, the appellative of patient (sick or not) is addressed to any person who is the beneficiary of healthcare services: as a cure or for prevention.

The medicalization of different life's moments, parts of the social life centuries before (Iacob, 2013, p. 66), imposes limitation of the personal freedom: the patient can't live anymore a life without the intrusion of the medical system in his social life. In this context (as a direct result of the life medicalization process), scientific publications on the topic mention cases when a medical intervention could be performed even without obtaining the patient's consent. One case concerns so called the obligatory medical treatments. Vaccinations and other types of preventive measures or treatments provided in epidemic contexts (Aluaş, 2016, p. 51) may be performed even without the consent of the person. In this kind of context, who will be in charge with the possible undesirable consequences on the receiver's health or life because of the medical intervention? This is not about malpractice, but about the fact that some persons may have, in the context of the vaccination campaigns, some unknown sensitivity or allergy to some components of the vaccine. If that will be the consequence, how will be indemnified that victim of a public health policy? This is the most important concern for the Covid-19 hesitancy (Pepplinkhuizen, 2020).

Nowadays no law is yet enacted, at international level or at national level in Romania, for the mandatory vaccination of the Romanian population - even if there are cases when must the records of the received vaccines demanded(in the case of intercontinental traveling or inscription at the school). In the last years, the vaccination rate for many diseases dropped in Romania (Vos, 2020); therefore some debates were raised around the need of the legislatively introduction of mandatory vaccination. And urged by the pandemic context, the Romanian governmental authorities made a proposal for outlining a law concerning mandatory vaccination. That legislative proposal stipulates a few situations for mandatory vaccination (by referring to some clear sanctions and restrictions in the case of noncompliance):

- "vaccinations included in the National Vaccination Calendar for children;

- vaccinations imposed by epidemiological situations involving vaccination as an intervention in order to limit diseases that may be prevented by vaccination;

- vaccinations for medical staff working in public and private health units;

- vaccinations for other staff working in public and private units who, by the nature of their duties, are additionally exposed to infectious diseases or may be sources of infection that could endanger public health, established by government decision." (Guvernul României, 2020)

However, European Court of Human Rights, recently, elaborated a paper with juridical character that was enacted with the purpose to protect the rights and the dignity of the human beings against the risk that the European member states may impose mandatory vaccination in the context of the Covid-19 pandemic. (Irish Sentinel, 2021) The mentioned text can be found on the website of the Parliamentary Assembly of the Council of Europe. In the third section of the seventh article is mentioned that no one can be discriminated for not being vaccinated. Moreover, in this text is mentioned clearly the interdiction of any pressures to get the vaccine: 
"7.3.1. ensure that citizens are informed that the vaccination is NOT mandatory and that no one is politically, socially, or otherwise pressured to get themselves vaccinated, if they do not wish to do so themselves;

7.3.2 ensure that no one is discriminated against for not having been vaccinated, due to possible health risks or not wanting to be vaccinated;" (Parliamentary Assembly, 2021)

The forth subsection (7.3.4.) urge for the distribution of "transparent information on the safety and possible side effects of vaccines, working with and regulating social media platforms to prevent the spread of misinformation" (Parliamentary Assembly, 2021). Applied with an ethical approach, the efforts performed in this direction would have a good contribution at reaching the necessary vaccination rate for the herd immunity (Pepplinkhuizen, 2020). This paper also make a recommendation about how to deal with the hesitancy: "take early effective measures to counter misinformation, disinformation and hesitancy regarding Covid-19 vaccines". (Parliamentary Assembly, 2021) Misinformation and disinformation are two unethical behaviors at the informational and communicational level which have as consequence the lack of important information that may help the individual to take the right decision (Vos, 2020). However, that affirmation concerning the hesitancy is still unclear in some aspects: can we place the hesitant attitude of a person or a group in the same category? For what reasons this kind of behavior could be considered unethical? Should we take action against it? For what reasons and by what means would be implemented this kind of actions? Even if this paper does not have the authority of an international law or convention, its formulation - by approaching similarly misinformation, disinformation and hesitancy - could be interpreted as a demand to treat any hesitancy as a crime against the society.

In the following section we will analyze the type of arguments brought by those raising their voice against the mandatory vaccination. The discourse about the present pandemic and the vaccination against Covid-19 is full of confusion concerning the terms and concept used; this confusion also characterizes the intentions with the public health policies implemented. What kind of behaviors are ethical and which ones are unethical and should be prohibited? If a person, by the international and national legislation, has the right to refuse vaccination based on some medical contraindications or religious/philosophical views to other vaccines currently used, we can assume that this person will have, firstly, a hesitant attitude. How can be worse to be hesitant than to have been decided to not get vaccine? This paper mention that no one will be discriminated for not having the vaccine, but all the efforts should be made against a hesitant attitude. Approaching in this way two almost similar concepts will lead to a real confusion in its interpretation. Moreover, can we forbid this hesitant person or decided to not getting the vaccine to share about her concerns on the Covid-19 vaccine as long as there is nothing about misinformation, disinformation or any other unethical behavior? This person probably will also use mass-media or social medial to let other people know about his personal decision to not get the vaccine based on some medical contraindication, some case of side effects to the Covid-19 vaccine or merely because of religious/philosophical beliefs.

\section{Considerations on the vaccination behaviors and practices}

\subsection{Arguments against mandatory vaccination}

Even if vaccination is considered, based on statistics and studies, to be a very effective preventive intervention (Bégué, 2010, p. 720), the oppositions to the legalization of the mandatory vaccination schedules or campaigns are as old as the vaccination itself. (Dr. Brouwer, 2011) With the time, the vaccines opposition was even augmented - many the antivaxx groups appearing around the world (Pepplinkhuizen, 2020). The arguments brought by 
them are based on different aspects concerning the production, the commercialization and the administration of the vaccines; but all of the arguments could be classified in the following categories: arguments based on medical reasonable grounds, questionable arguments, oppositions based on believes and personal convictions, rumors and pseudo-science (Bazin, 2010). Nowadays - in the context of Covid-19vaccine - some of the reasons are changed, but the same categories still remain.

The most important reasons of being against the vaccination are based on the interpretations and fears related to its medical aspects. Historically, at the beginning of their use, a huge cause of the vaccines' rejection was the fear of contamination (Bazin, 2010, p. 707). In the present, the safety of the production and administration of the vaccines is one of the priorities - the medical biotechnologies are well improved. Therefore, the risk of contamination is very low (Vaccins et demain? - dossier, 2010). Other two fears, brought even today by some groups, concern the safety of the vaccine itself, along with the risk to have some personal biological sensibilities or a kind of immune response that may lead to serious side effects to the vaccine (Dr. Brouwer, 2011). Even if the probabilistic knowledge concerning the physiological response to vaccines was improved and the technologies of their production were changed significantly, those concerns were highlighted by recent studies as the most important aspects in the decision to get the Covid-19 vaccine. A study by Lazarus and his team (2020) on the acceptance of Covid-19 vaccine showed that "71.5\% responded that they would take a vaccine if it were proven safe and effective" (Lazarus, 2020, p. 3).

The second type of reasons listed by the opponents to vaccination is questionable because it is not possible for them to prove their arguments based on official statistics. Here we can talk about the conviction of some individuals, that the diseases may disappear on their own or only as an effect of hygiene or through natural immunization. (Bazin, 2010, p. 708709; Autrive et al., 2003). This approach is not directly related the Covid-19 vaccination campaign, but having those ideas on the background of the mind, the population will be more prone to refuse getting the Covid-19 vaccine.

At the level of personal believes and convictions, a person would refuse the vaccine despite of her a strong conviction about the vaccine efficacy: this kind of decision is based merely on philosophical or religious view of the world (Bazin, 2010, p. 710-713).Therefore, an individual may consider the vaccination as: an attack on providence and trust in divinity, an immoral act (especially, in the case of the vaccines that may prevent sexual transmissible diseases), an attack to the personal freedom, a sin because of using human or fetal tissues on their production, a foreign administrative intrusion in their own country. This king of arguments may influence strongly the Covid-19 vaccines' oppositions as long as, in this pandemic context, the population was confronted severely with the limitation of the personal freedom. In this context, many social media influencers brought attention on the arguments supporting their strong skepticism about the future evolution of the personal freedom (Ferro \& Miotto, 2017; Vos, 2020). The people who are strongly attached to their moral - and religious believes - arguments for their decision to refuse the vaccination has the tendency to consider the intrusion of the medicine in the social and personal sphere of life as a new form of religious system:

"The faith in this new religion became, in the present, a real fanaticism and the gods were replaced by mandarins and experts. We don't think anymore, we "believe". We could excuse Shaw for saying that "the science is a new religion and la vaccination is its Holy water".” (Simon, 2009, p. 219)

The last category of arguments is represented by rumors and pseudo-science. This category of arguments mat also be include the attacks on the name or character of some personalities in the fields related to the vaccination (Bazin, 2010, p. 713-717). Definitely, the information spread by this kind of arguments is not based on medical evidences proved by 
studies and statistics. However, people will talk about stories built around some vaccines adding a few facts based even on some medical data. In order to support their decision to not get the vaccine, people can spread and catch: conspiracy theories (Lazarus, 2020), urban legends (Ferro \& Miotto, 2017) as stories shared on social platforms and pseudo-medical forums, the subjective experience of their acquaintances. Even if those kinds of narrative arguments existed from the beginning of the vaccination, in the present context of Covid-19 vaccine development and implementation of the vaccination campaigns, the governmental and medical authorities have to face a lot of disinformation (Pepplinkhuizen, 2020). Some of the conspiracy theories arrived to the promotion of the idea that in the development of the Covid-19 vaccine will be used biotechnologies that will allow to the mentioned authorities controlling the behavior of the population. There is supposed to be even a link between the vaccine and the $5 \mathrm{G}$ mobile networks.

\subsection{An ethical-philosophical reflection on the right for Covid-19 vaccines hesitancy}

Taking into account all the categories of arguments mentioned above, the most reasonable ones are those that rely on medical aspects and, therefore, can be analyzed from a medical perspective by some independent researchers or by observing the official statistics. As a good example of an ethical debate about the Covid-19 vaccine based on medical facts is the approach brought by a few medical professionals had some concerns on the following aspects: the shortening of the study phases for the new vaccine development, the uncertainty about what side effects may occur after vaccination (in medium and long term), the uncertainty about the risk / benefit ratio between the disease itself and the vaccine (Williams, 2020).

By contrast, the narratives built and shared about this disease and Covid-19 vaccine have a subjective character. However, a subjective experience cannot be denied because each person has different perceptions concerning the personal embodied process. However, the theoretical construct built on a subjective experience, the link between different social events or the motivation assumed to be behind the governmental and medical authorities' action to implement certain public health policies can be analyzed by an ethical approach. Two important pillars in this approach will be: to document the objective evidences of certain stories and to analyze the logical validity of the arguments' construction.

The arguments based on personal believes and conviction for the vaccines' refusal have their focus on the morality of the vaccination as an act that may transgress the philosophical or religious views on the freedom and dignity of the human being. Those moral interpretations consider some of the aspects of the medicalization of the personal and social life to be a biopowers (Foucault, 2007) implemented to control the individual in his private sphere of living: biopolicy concerning the personal life aspects of the citizens.

At the base of the contemporary development of the clinical practice, we can find the four principles of biomedicine: autonomy, nonmaleficence, beneficence and justice (Beauchamp \& Childress, 2013). Each of those four principles is supposed to be applied simultaneously in all medical contexts. But, unfortunately, as a result of their focus on the health, the disease and the individual himself, different medical departments may arrive even to an opposing approach of the same case. As an example, the public health service has its focus on the health of the general population and not on the patient as one individual. Therefore, the medical decisions taken by the public health system are based on statistics and not on particular cases. Or this aspect, for the most of the patients is less relevant as long as their case can be represented by the small percentage of those who may have serious side effects to the vaccine (Autrive et al., 2003). Moreover, in the vaccination context, it is about a preventive action. Or, the patient tends to be less prone to accept a medical intervention in the absence of pain and suffering (Bazin, 2010). 
Most of the contemporary thinkers describe the present living context as a risk society (Pestre, 2013, p. 115). By consequence, each person must to choose between different kinds of risks in any medical decision. In the pandemic context of Covid-19, decision of the patient risk is between the illness itself and for the risk supposed by the vaccination. Some very important questions, from the ethical-philosophical perspective will be: is the patient aware that his existence takes place in a risky society? Is he aware that his choice is between the risk of the disease itself and the risk induced by vaccination? The individual is focused on preserving the present state of health and avoiding all possible risk of getting sick. Despite the technological progress, we still have to choose between different risks and dangers. From this approach, the concern of those who have to take a decision is about the statistical data of the dangers of the disease itself in rapport with the supposed risks of the vaccination. In the present, maybe, we still miss the complete data on medium and long term of Covid-19 vaccines, as some healthcare professionals suggest (Williams, 2020). In the same time, it is not possible for our society to wait a few years before taking action to stop the spreading of the SARS-Cov-2 virus.

Because of the present context and the urge to take rapid decisions, the public health system has to deal with the perception of the individual in relation with his own body, but also in relationship with others. Does the individual consider that his body belongs to him or does he only himself as benefiting from its use? What is the real status of the body in the public space? To whom does the biological body "belong"? Who can make decisions and to whom does the responsibility belong? By answers at these questions, each individual will attribute a certain value to the personal wellness and that one of the community.

To stop the spreading of the Covid-19 disease, the rights of the individuals were limited, but what kind of decisions can be made intrusively? Is this acceptable from the highest moral point of views? To what extent are the legislative decisions taken by public health system in accordance with the public discourse on the status of the body, being supported by it? Is that discourse based on ethical foundations or are there issues that may lead to abuse against vulnerable groups? The discourse about the vaccination against Covid19 is focused a lot on mentioning about the vulnerable groups, but how do we define the idea of "vulnerable group"? It is about the vulnerability in relation with their lack of knowledge concerning the disease and the vaccine or about the vulnerability of getting the disease, being too much exposed? Most of the discourses mention about the last kind of vulnerability promoting the arguments for the vaccination. But, in a pandemic context, the first mentioned kind of vulnerability could be more dangerous sometimes. It is important to know if a decision is taken because of the lack of knowledge or because of other kind of subjective reasons. Each one of these groups should be treated differently. A person may be hesitant based on some subjective personal reasons - philosophical, religious - and nobody has the right to act against the conscience of one individual. Moreover, a person has the right to take a certain decision concerning her own person even without explaining this attitude. This is a natural and fundamental human right.

The international legislative documents highlight that the vaccination against Covid19 cannot become mandatory and no one can be the target of any kind of pressure or discrimination. But how exactly will be defined the terms of mandatory vaccination, pressure or discrimination? In order to avoid any misinterpretation and to assure good respect of the human dignity and rights, the mentioned terms should be clearly defined and described, by the international documents, for their appropriate contextual use or for the implementation of some actions based on them.

Plenary approach on the freedom concept of the philosophico-theological thinking of the Middle Ages applied to the ethical considerations on the mandatory vaccination proposals for the present pandemic context 
The concept of freedom has a long history in the philosophical thinking, being debated by its integration in conceptual constructs based on theological or naturalist views of the world. But a plenary view of the freedom concept is rooted in the theological philosophy which sees the divinity in the center of the mundane existence, offering the free will to the human being for taking an independent decision. Does God take any action to prevent a certain decision or a hesitant attitude? The predestination was an important issue in the Middle Ages' debates. Augustine was one of the most important philosophers and theologians that wrote on this topic, answering to the Pelagius' heresies. This important thinker supported the idea that, even if God knows the decision and its consequence - for a certain person - He will not predestinate any person to a certain destiny (life and type of judgment) (Augustin, 1886, p. 1399). The Christianity of the Middle Ages was confronted, for a few centuries, with debates on this topic. Even if the sovereignty of God was accepted without doubt, the debates' focus was on the responsibility of the human beings for their actions and the dignity given by the possibility to take independent decisions (Forlines, 2011). These two aspects were considered to be fundamental for the quiddity of the human being and existence.

Considering the idea of not being a priori predestined to a certain kind of life and the freedom concerning the personal decision, we can draw an analogy between this Middle Ages' theological topic and the present vaccination context. This analogy can also be supported by the thinkers that sees it (the vaccination along with the medicine itself) to have the same functions in the present society as the religion in the earlier centuries (Simon, 2009, p. 219). By statistics of the vaccination programs implemented in the present, a part of the population is immunized, a certain percentage is not immunized, without affecting their health, but it will remain a small part of the population with side effects because of their sensitivity to the vaccines' components. Even if we have estimations, it is yet too early to have a clear image of each category's percentage for the population to be vaccinated against Covid-19. However, can we "predestine" different categories of the population for a certain quality of life? If we only knew exactly which one of these people is in each of the three categories, will we make the same decision based on non-discrimination principle? Not knowing their identity could be taken as an excuse to promote mandatory vaccination or for conditioning other rights on getting the vaccine. But the fact that we do not know ahead their identity - still knowing that these groups exist, based on the previous vaccines statistics - is a sufficient argument for condemning a hesitant attitude and putting it in the category of dangerous behaviors? A superficial approach of this question may lead to a slippery slope evolution toward the mandatory vaccination without exceptions, which from a plenary view of the freedom concept is unethical and dangerous.

How can we prevent the evolution of slippery slope kind of reasoning and legal acts' interpretation toward the mandatory vaccination imposed by law? Is it ethical, at all costs, to conduct pre-vaccination testing in order to find out if there are high chances for a patient to suffer from serious post-vaccine side effects or the opposite behavior should be considered the ethical one? What ethical implications, concerning the responsibility of actions, may have to know or not if the body of a certain individual will have a certain type of response to the vaccine? Is the vaccination a context in which the morality of an action is decided by the society as a corpus (by the majority of the votes) or is it necessary to be based on an individual moral reflection (that will be validated and respected at the community level)? Should the approach of the preventive public health policies be based on a deductive or inductive construction of the ethical reflection? How is the patient educated in this regard to understand the construction of the arguments that stand at the foundation of the vaccination efforts? The government and the medical authorities may propose and implement certain preventive public health policies, but, in the same time, they have to take the full 
responsibility on the health of the citizens by considering ahead the questions above. Otherwise, the patient has the full right to be hesitant on any public health policy proposal.

The questions mentioned above should find answers or, at least, to give the opportunity to think deeper to those who plan and implement the vaccination campaigns against Covid-19. Indeed this topic is a tough one, with a lot of ethical, medical social implications at different levels of the society, but the way of how the vaccination campaigns appear to be planned, through mass-media and social media, and the discourse around this topic let the impression of not caring enough about the psycho-emotional issues and personal values of the citizen in taking a certain decision at the public level.

\section{Conclusion}

The human being living in the present society has to assume certain risks taking most of the decisions, especially those concerning the medical field. When a person will opt for a decision in the context of Covid-19 pandemic, he/she has to be aware that the decision is between the dangers of the disease itself and the risks of the vaccines. For the moment, the healthcare professionals don't have the final statistics on medium and long term concerning the vaccine, but they have better statistics about the dangers of the Covid-19 disease.

The ethical-philosophical concern raised by this context is about how the vaccination campaigns are managed and how the population is informed and supported in taking the right decision that will augment the beneficence for all the involved parts and, in the same time, will lower the danger rates of illness by Covid-19 or acquired as side effects to the vaccination. The wrong handling of this vaccination campaign against Covid-19 may contribute to the conspiracy theories' spreading that will undermine the trust of the population on the medical system and in the government. Therefore, those two public authorities have to give the impression of a good interest in the population's health, by proving comprehension and empathy toward their worries. A fundamental question to ask in leading the public campaigns of vaccination against Covid-19 is: Will this public health policy as a whole, contribute at improving the population's confidence in the health system / the medical staff and the government or will it undermine their trust on long term?

The focus of the public health policies and the government is on the wellness of the community as a whole, but the structural component of the community is the individual. The community is formed by each individual, not just by some citizens. In a society where just the majority or some individuals matter based on some discriminatory criteria, a person may be regarded as not important, at any moment, and to be pushed to assume some uncomfortable risks. Could we find an approach whereby individual and collective interests are not in opposition? Studies proved that the population is more prone to accept the vaccine if this is perceived as being a personal decision. (Lazarus, 2020, p. 3) To what extent does the patient feels his own person as a part of the decisions taken in the present pandemic context? The language used in the international documents and in mass-media is not the best chosen to build the trust and the cooperation at the community level.

By a philosophical approach of this topic, the focus should be on establishing the involved concepts, making explicit for the population their definition for the present context, analyzing their implications in leading the vaccination campaigns against Covid-19 and their impact on the population' decision by the use of certain discourse on the present topic. Moreover, one of the most important aspects in the assurance of the highest ethical standards of the vaccination campaigns is to ask the right questions in planning and implementing these preventive public health policies. The present article was focused, by ethico-philosophical reflections on the topic, on finding some important questions to be asked in the present pandemic context. From a philosophical approach, there is a plurality of sides to observe in the vaccination campaigns against Covid-19. Denying even one subjective side or view on 
the present context promoted by some groups will lead, probably, at breaking the communication and their trust, at long term, in the health system and government.

\section{References}

Aluaş, M. (2016). Bioetică Medicală. Cluj-Napoca: Medicală Universitară „Iuliu Hațeganu”.

Asveld, L. (2008). Mass-vaccination programmes and the value of respect for autonomy. Bioethics, 22(5), 245-257.

Augustin. (1886). A Treatise On The Predestination Of The Saints Nicene and Post-Nicene Fathers 1-05. (P. Schaff, Ed.) Edinburgh: Wm. B. Eerdmans Publishing Company.

Augustin. (2002). Despre liberul arbitru (ediţie bilingvă ed., Vol. Opera omnia vol. 2). (V. Sav, Trans.) Cluj-Napoca: Editura Dacia.

Autrive, P., Buchwald, G., Clements, J., Dunbar, B., Gaublomme, K., Georget, M., . . . Shattock, P. (2003). Les vaccinations en question (Collection La preuve écologique ed.). Paris: Frison-Roche.

Bazin, H. (2010). Histoire des refus vaccinaux 2010. Bull. Acad. Natle. Med., 194, $n^{o}$ s 4 et 5 , 705-718.

Beauchamp, T. L., \& Childress, J. F. (2013). Principles of Biomedical Ethics (seventh edition ed.). Oxford: Oxford University Press.

Bégué, P. (2010). Conséquences des oppositions vaccinales en France et en Europe. Comment maintenir une couverture vaccinale efficace en 2010?, Bull. Acad. Natle. Med., 194, $n^{o}$ s 4 et 5, 719-732.

Bégué, P. (2010). Séance dédiée a la vaccination et société. présentation. Bull. Acad. Natle. Med., 194, $n^{o}$ s 4 et 5, 703.

Carr, S. (2019). The Synod of Dort Was Protestantism's Biggest Debate. Why Arminians and Reformers squared off 400 years ago. Christianity Today. https://www.christianitytoday.com/history/2019/december/synod-dort-reformerarminianism-tulip.html

Chamayou, G. (2014). Les corps vils. Experimenter sur les etres humains au XVIIIe et XIXe siecles. Paris: La Decouverte.

Colegiul Medicilor din România. (2016, November 4). Codul de deontologie medicală (2017). https://www.cmb.ro/legislatie-colegiu-cod-deontologic/

Council of Europe. (1997, IV 4). Convention for the Protection of Human Rights and Dignity of the Human Being with regard to the Application of Biology and Medicine: Convention on Human Rights and Biomedicine (Oviedo). https://www.coe.int/en/web/conventions/full-list//conventions/rms/090000168007cf98

Covid-19 vaccines: ethical, legal and practical considerations. (2021). Parlamentary Assembly. $\quad$ https://pace.coe.int/en/files/29004/html?fbclid=IwAR2MzKJ4ga57jYYtc7ZpCQwYiYSQALVk7UOjy4J3ftEFvWuROqYn6Gjmtg

Danzon, M. (2010). Décision et controverses. Les Tribunes de la santé, 2(27), 111-116.

Dr. Brouwer, L. d. (2011). Vaccinarea: eroarea medicală a secolului - Pericole și consecințe. (N. Radu, Trans.) Bucarest: Vida.

Ferrell, V. (2004). The Vaccination Crisis. Altamont, NT, USA: Harvestime Books.

Ferro, A., \& Miotto, S. (2017). Urban legends and vaccines. In Vaccinars in Sadergna: Urban legends and vaccines

Forlines, F. L. (2011). Classical Arminianism. A Theology of Salvation. Nashville: Randall House Publications.

Foucault, M. (2003). The Birth of the Clinic. London: Routledge.

Foucault, M. (2007). Naşterea biopoliticii. (B. Ghiu, Trans.) Cluj: Ideea\&Design Print.

Foucault, M. (2009). Securitate, teritoriu, populaţie. Cluj: Idea Design \& Print. 
Gauchet, M. (2006). Ieșirea din religie. (M. Antohi, Trans.) Bucharest: Humanitas.

Guvernul României. (2020). Proiectul de Lege privind organizarea şi finanţarea activității de vaccinare a populaţiei în România, adoptat de Guvern. https://www.gov.ro/ro/guvernul/sedinte-guvern/proiectul-de-lege-privind-organizareasi-finantarea-activitatii-de-vaccinare-a-populatiei-in-romania-adoptat-de-guvern

HealthGuard. (n.d.). The Top Covid-19 Vaccine Myths Spreading Online. https://www.britannica.com/list/the-top-covid-19-vaccine-myths-spreading-online

Hirsch, E. (Ed.). (2007). Ethique, medecine et societe. Comprendre, reflechir, decider. Paris: Librairie Vuibert.

Iacob, I. F. (2013). Sănătate, boală, vindecare: O perspectivă socio-culturală. Cluj: Pressa Universitară Clujeană.

Irish Sentinel. (2021). European Court of Human Rights : Voted that prohibits member states from making vaccination against the coronavirus mandatory. Irish Sentinel. https://theirishsentinel.com/2021/01/29/european-court-of-human-rights-voted-thatprohibits-member-states-from-making-vaccination-against-the-coronavirusmandatory/?fbclid=IwAR1EfJw_M8Dr9xfrKsOwQHdVe91XZHL_5efFPxhyhmwjO1fmOO2n1USt7M

Katznelson, B. (2020). Politics vs. science: the politicization of Covid vaccination. https://www.urbanlegendnews.org/uncategorized/2020/11/19/politics-vs-science-thepoliticization-of-covid-vaccination/

Lazarus, J. V. (2020). A global survey of potential acceptance of a Covid-19 vaccine. Nature Medicine, 2-10.

Oprea, L., Gavrilovici, C., Vicol, M. C., \& Astărăstoaie, V. (2013). Relaţia medic-pacient. Iaşi: Polirom.

Parlamentul României. (2003). Lege nr. 46/2003 drepturilor pacientului. Monitorul Oficial al $\begin{array}{lllll}\text { României } & n r & 51 & \text { din } & \text { 2003-01-29. }\end{array}$ http://legislatie.just.ro/Public/DetaliiDocument/41483

Parlamentul României. (2017). Lege privind organizarea și finanțarea activității de vaccinare a populației în România. http://www.ms.ro/wpcontent/uploads/2017/04/LEGEA-VACCINARII-10.04.2017-002.pdf

Parliamentary Assembly. (2021). Covid-19 vaccines: ethical, legal and practical considerations. https://pace.coe.int/en/files/29004/html?fbclid=IwAR2MzKJ4ga57jYYtc7ZpCQwYiYSQALVk7UOjy4J3ftEFvWuROqYn6Gjmtg

Pepplinkhuizen, M. (2020). KU Leuven working with other European institutes to understand vaccine hesitancy. Veto. https://www.veto.be/artikel/ku-leuven-working-with-othereuropean-institutes-to-understand-vaccine-hesitancy

Pestre, D. (2013). A contre-science. Politiques et savoirs des societes contemporaines. Paris: Seuil.

Simon, S. (2009). Vaccins, Mesonges et Propagande. Vergeze: Thierry Souccar Editions.

Truchet, D. (2010). L'avenir de l'obligation vaccinale: aspects juridiques. Bull. Acad. Natle. Med., 194, $n^{o}$ s 4 et 5, 733-740.

UPMC. (2020). COVID-19 VACCINATION. COVID-19 Vaccine Myths and Facts. UPMC Health Beat. https://share.upmc.com/2020/12/covid-19-vaccine-myths-facts/

vaccinations, L. (2010). Dossier, adsp (actualité et dossier en sante publique), $n^{o} 71$.

Vaccins et demain? - dossier. (2010). Biofutur, 306.

Vos, E. (2020). Mandatory Vaccination in Romania: Back to Vax. Pharma Boardroom. https://pharmaboardroom.com/articles/mandatory-vaccination-in-romania-back-tovax/

Williams, L. (2020). Covid vaccine: even healthcare workers may be hesitant - but new evidence can be reassuring. The Conversation. https://theconversation.com/covid- 
vaccine-even-healthcare-workers-may-be-hesitant-but-new-evidence-can-bereassuring- 151404 